\title{
Quantifying recycled moisture in precipitation in Qilian Mountains
}

\author{
guofeng zhu ${ }^{1}$, Hanxiong $\mathrm{Pan}^{2}$, Zhigang Sun ${ }^{1}$, Zhuanxia Zhang ${ }^{1}$, Liyuan Sang ${ }^{1}$, and Huiwen \\ $\mathrm{Guo}^{1}$ \\ ${ }^{1}$ Northwest Normal University \\ ${ }^{2}$ Taizhou University
}

August 13, 2020

\begin{abstract}
Studies based on basins or regional scales often ignore the uniqueness of recycling moisture in mountain areas, and little effort has been made to understand the impact of the local recycled moisture on precipitation in mountain areas. We collected and analyzed a series of samples (stable isotope of precipitation, soil water, plant water, runoff, and groundwater) in the Qilian Mountains, northwest of China. Based on the isotopic mixing model, the characteristics of recycled moisture in the Qilian Mountains were assessed. The results showed that lateral advection moisture is the primary source of precipitation (83.5 98.38\%). The contribution rate of recycled moisture to precipitation was higher in spring, summer, and autumn (2.05 16.5\%), and lower in winter $\left(1.62^{\sim} 3.32 \%\right)$. The contribution of recycled moisture to precipitation in the high-elevation areas $(>2400 \mathrm{~m})$ was higher than that in the foothills area $\left(2300^{2} 2100 \mathrm{~m}\right)$. The contribution of vegetation evapotranspiration (fTr) to precipitation in the east of Qilian Mountain was higher than that of the land surface evaporation (fEv).
\end{abstract}

\section{Hosted file}

manuscript-20200813.doc available at https://authorea.com/users/285781/articles/475526quantifying-recycled-moisture-in-precipitation-in-qilian-mountains

\section{Hosted file}

Figure.doc available at https://authorea.com/users/285781/articles/475526-quantifyingrecycled-moisture-in-precipitation-in-qilian-mountains

\section{Hosted file}

Table.doc available at https://authorea.com/users/285781/articles/475526-quantifyingrecycled-moisture-in-precipitation-in-qilian-mountains 